\title{
Retrospective analysis of Austrian health recording data of antibiotic or nonantibiotic dry-off treatment on milk yield, somatic cell count, and frequency of mastitis in subsequent lactation
}

\author{
T. Wittek, ${ }^{* 1}$ A. Tichy, $†$ B. Grassauer, $\ddagger$ and C. Egger-Danner§ \\ *University Clinic for Ruminant, and \\ †Bioinformatik und Biostatistik, Vetmeduni Vienna, Veterinärplatz 1, A1210 Vienna, Austria \\ $\ddagger$ Tierarztpraxis Grassauer Ratschfeld 44, A8853 Ranten, Austria \\ §ZuchtData-EDV-Dienstleistungen GmbH, Dresdner Straße 89/19, A1200 Vienna, Austria
}

\begin{abstract}
Typically, dairy cows are dried off at the end of lactation. During the dry period, intramammary infections may be cured or persist, and new infections may occur. Traditionally, antibiotics (AB) have been used at dry-off. However, blanket antibiotic dry-off treatment may no longer be justifiable and, recently, selective use of antibiotics at dry off has been proposed and different decision criteria suggested. The objective of the study was to evaluate cows receiving antibiotic treatment at dry off (AB group) compared with cows dried off without antibiotics (non-AB group) using a large data set. Primary outcome parameters were milk yield, somatic cell count (SCC), and frequency of mastitis in the subsequent lactation. Additionally, we aimed to calculate cut-off values to determine, at the cow level, whether antibiotic dry-off treatment is indicated. A data set of 88,534 lactations was used; 27,723 cows were dried off using antibiotics (AB group; 31.3\%) and 60,811 cows were dried off without antibiotics (non-AB group; $68.7 \%$ ). Milk yield in previous and subsequent lactations was higher in the $\mathrm{AB}$ group. Cows in the $\mathrm{AB}$ group produced, on average, $91 \mathrm{~kg}$ more milk in the subsequent lactation. The average SCC during the final $90 \mathrm{~d}$ of the previous lactation and at dry-off did not differ between the 2 groups. The probability of drying off using antibiotics increased almost linearly with higher milk yield and with higher SCC. The use of antibiotics resulted in an average decrease in SCC of 1,500 cells/mL in the subsequent lactation. The frequency of clinical mastitis during the previous lactation was higher in the $\mathrm{AB}$ group than in the non- $\mathrm{AB}$ group. Independently of the dry-off treatment, this difference remained in the subsequent lactation within $90 \mathrm{~d}$ in
\end{abstract}

Received June 22, 2017.

Accepted September 27, 2017.

${ }^{1}$ Corresponding author: Thomas.Wittek@vetmeduni.ac.at milk. The use of antibiotics at dry-off had no significant effect on the frequency of mastitis within $90 \mathrm{~d}$ in milk of the subsequent lactation. The study indicates that Austrian farmers and veterinarians are applying selective dry-cow treatment using milk yield and, to a lesser extent, SCC and mastitis frequency, for decisionmaking. However, even though a large data set was used, cut-off values with sufficient diagnostic value for selective dry-cow treatment could not be identified. It is likely that cut-off values must be identified at the herd level or in combination with additional parameters (e.g., results of bacterial culture).

Key words: dry-off treatment, antibiotics, selective dry-cow treatment

\section{INTRODUCTION}

Typically, dairy cows are dried off at the end of lactation. During the dry period, IMI might be cured or persist and new IMI may occur. Green et al. (2002) found that the presence of bacteria at drying off and during the dry period increased the risk for clinical mastitis after calving. Numerous dry-period cow, farm, and management factors have been identified that influence udder health after calving (Green et al., 2007). For example, cows producing higher levels of milk on the day before dry-off are significantly more likely to develop a new IMI during the dry period; however, whether milk yield at dry-off affects the risk of IMI during the dry period or subsequent lactation is the subject of debate (Dingwall et al., 2001, 2004).

The use of antibiotics in dry cows was originally introduced to prevent the "summer mastitis" caused by Trueperella pyogenes over $60 \mathrm{yr}$ ago (Pearson 1950, 1951). Antibiotics were later applied as general dryoff treatment (Smith et al., 1966, 1967). Since then, numerous studies have described the benefit of blanket antibiotic treatment at dry-off (Bradley and Green, 2001; Berry and Hillerton, 2002; Robert et al., 2006). However, concerns that blanket antibiotic dry-off 
treatment may result in resistance to antibiotics have brought its use into question. More recently, selective use of antibiotics at dry-off was proposed and certain criteria were proposed for use in deciding whether antibiotics should be used or not. The most critical factor for decision-making is whether an IMI is present at dry-off (Huxley et al., 2002; Robert et al., 2008; Torres et al., 2008). Various parameters such as results of bacteriological culture (Robinson et al. 1988, Browning et al., 1990) and on-farm culturing (Cameron et al., 2014), SCC and clinical mastitis history (Rindsig et al., 1978; Torres et al., 2008; Rajala-Schultz et al., 2011; Bhutto et al., 2012; Scherpenzeel et al. 2014), conductivity (Roy et al., 2009), and $N$-acetyl- $\beta$-D-glucosaminidase (Hassan et al., 1999) have been suggested; however, their diagnostic value varies considerably. Somatic cell count is considered an excellent proxy for IMI (Dufour et al., 2011). Torres et al. (2008) reported that monthly measured SCC is probably the most commonly used criterion because it is readily available on the milk recording reports. Robert et al. (2006) analyzed the available literature at that time and found that selective dry-cow treatment resulted in a 1.7-times-higher risk of IMI during the dry period than did blanket antibiotic treatment. Other studies found only minor or no differences between blanket and selective antibiotic use at dry-off (Halasa et al., 2009a,b; Cameron et al., 2014). Teat sealants have been used in combination with or as an alternative to antibiotic dry-off treatment. The meta-analysis by Rabiee and Lean (2013) on teat sealants showed that application of teat sealants alone or in combination with antibiotics as dry-off treatment was effective to reduce the incidence of IMI during the dry period and clinical mastitis after calving.

To the best of our knowledge, no data are available on dry-cow treatment in Austria and it is not known how many cows are dried off on the basis of the results of bacterial culture. However, we assume from our practical work and from the samples submitted to our diagnostic laboratory that this remains an uncommon procedure. Further, no national data are available on prevalent microorganisms associated with mastitis in Austrian dairy cows. Results from our own laboratory ( $>10,000$ bacterial culture samples/yr) indicate that CNS $(\sim 30 \%)$, Streptococcus uberis $(\sim 19 \%)$, and Staphylococcus aureus $(\sim 19 \%)$ are the most frequently isolated microorganisms in milk samples from cows with mastitis.

Most current studies on dry-cow treatment have been performed on a limited number of farms or animals, and no studies based on larger data sets are available. The objective of this study was to evaluate, in a large data set, the application of long-acting antibiotic treatment to cows at dry-off compared with cows dried off without antibiotic treatment. Additionally, we aimed to calculate cut-off values for use in deciding whether antibiotic dry-off treatment is indicated at the cow level.

Our main hypotheses were that (1) a considerable number of farmers and veterinarians in Austria have already changed from blanket to selective dry-off treatment; (2) antibiotic dry-off treatment affects milk yield, SCC, and frequency of mastitis during the dry period and the subsequent lactation; and (3) suitable cut-off values can be established to determine when antibiotic dry-cow treatment is indicated.

\section{MATERIALS AND METHODS}

A large database comprising data on milk yield and health data from dairy cattle in Austria was used. A nationwide health monitoring system for cattle in Austria was established in 2006 and has been routinely recording health data since 2010 (Egger-Danner et al., 2012, 2013). The data set was provided by ZuchtData EDV-Dienstleistungen GmbH (Vienna, Austria).

The data set Gesundheitsmonitoring-Rind (Austrian health monitoring system for cattle) contains data on veterinary diagnoses for individual dairy cows and for calves, heifers, breeding males, and beef cattle. The diagnoses are documented by veterinarians and recorded by employees of the performance recording organizations or transferred directly by the veterinarian to the central cattle database. Breeding organizations of all substantial cattle breeds in Austrian $(>90 \%$ of the cattle) use these data on health traits in their breeding programs. Veterinary diagnoses are recorded from about $70 \%$ of Austrian dairy cattle farms. The average herd in Austria is small (20 cows); most family-run farms keep between 15 and 60 cows and a very small number of herds have more than 100 cows. This study only included farms from which data were sent directly by the veterinarian to the central cattle database.

The diagnoses of interest for this study were "acute clinical mastitis" (code 51) and "subclinical chronic mastitis" (code 52). The records were evaluated to determine whether a long-acting antibiotic dry-off treatment had been administered to the cow or not (code $56)$.

Information about diagnoses, treatments, and prophylactic measures is electronically transmitted by veterinarians into the cattle database, which includes animal identification, calving, and other data from performance recording. The database includes herd information as well as cow-level data (e.g., milk yield and SCC during the lactation). These parameters are recorded, on average, every $40 \mathrm{~d}$. Cow-level data for milk yield, SCC, and veterinarian diagnoses of acute and chronic mastitis were used. 
The data were filtered for suitability and validity and had to meet the following conditions: farms used direct electronic transfer of data to the cattle database; farms and veterinarians used all 3 codes $(51,52,56)$ of the health monitoring system; veterinarians regularly used the system and had more than 1,000 records; cows were of Fleckvieh (Simmental) breed (the dominant breed in Austria); cows were between second and sixth lactation; cows were present on the farm at least $120 \mathrm{~d}$ before calving and until 90 DIM; cows for which the parameters for milk yield and SCC were available for at least $6 \mathrm{mo}$ in the previous lactation before and $6 \mathrm{mo}$ after dry-off treatment; and treatment code 56 (antibiotic dry-cow treatment) was recorded in the system between 120 and $30 \mathrm{~d}$ before calving

Data used for the study were checked for plausibility and validated with respect to continuous recording of health data. The correctness of data preparation was crosschecked with a smaller sample of farms where the veterinarians confirmed a very high reliability of documentation of diagnoses and dry-off treatments. The data from the cattle database on a smaller sample of farms were evaluated compared with raw data collected by the veterinarian.

The data set did not provide information on the exact length of the dry period because entering "code 56 " in the data set indicated only that the farmer was supplied with the dry-off antibiotic tube for a specific cow, not that it was necessarily applied on the same day. Further, no specific information was available about whether farms were using blanket or selective antibiotic dry-off treatment or which criteria were applied by the farmer to decide whether a certain cow was dried off with or without antibiotics.

Two groups were defined on the cow level according to the dry-off procedure: (1) cows that had been dried off by applying an antibiotic treatment (AB group; the following drug combinations are currently licensed as dry-off formulations in Austria: penicillindihydrostreptomycin, cloxacillin-ampicillin, rifaximin, framycetinsulfate, benethamin-penicillin, penethamate hydroiodide); and (2) cows that were dried off without the application of an antibiotic (non-AB group).

Parameters of interest to characterize the lactation before dry-off treatment were 305-d milk yield, daily milk yield at dry-off, average SCC during the $90 \mathrm{~d}$ before dry-off, SCC at dry-off, and frequency of subclinical or clinical mastitis in the lactation before dry-off.

For the subsequent lactation, the outcome variables were milk yield during subsequent lactation (305 d), average SCC within 90 DIM, and frequency of subclinical or clinical mastitis within 90 DIM. Only the period of $90 \mathrm{~d}$ in lactation was considered because events later in the lactation were assumed less likely to be related to dry-off treatment in the previous lactation.

Data analysis was performed using the statistics program SPSS 20.0 (IBM Corp., Armonk, NY). Descriptive statistics were calculated (frequency of mastitis, milk yield, SCC) for the previous and subsequent lactations. Data are presented as arithmetic mean \pm standard deviation. Normal distribution of the metric data was tested applying the Kolmogorov-Smirnov test. Parameters that were not normally distributed were log-transformed before further analysis. Parameters were compared between lactations (previous and subsequent) and between the 2 treatments using $t$-test and Chi-squared test. For all analyses, a $P$-value $<0.05$ was considered indicative of significant differences.

A linear mixed model analysis was performed for outcome variables in the subsequent lactation: milk yield, SCC, and frequency of mastitis (to 90 DIM), with dryoff method ( $\mathrm{AB}$ or non- $\mathrm{AB}$ ), occurrence/frequency of clinical mastitis in previous lactation, and occurrence/ frequency of SCC >200,000 cells $/ \mathrm{mL}$ in previous lactation as fixed factors, and milk yield of previous lactation, milk yield at dry-off, average SCC during $90 \mathrm{~d}$ before dry-off, SCC at dry-off, lactation number, year, season, farm, and veterinarian as covariates. The animal was added as a random factor. Logistic regression analysis was applied to estimate if farmers and veterinarians use parameters such as milk yield or SCC for decision making if cows are dried off with or without antibiotic treatment.

In addition, receiver operating characteristic (ROC) curve analyses were performed to determine potential cut-off values of parameters (SCC, milk yield) on different outcomes such as mastitis or subclinical mastitis for $\mathrm{AB}$ and non- $\mathrm{AB}$ groups separately.

\section{RESULTS}

\section{$A B$ or Non-AB Dry-Off}

A large data set of 95,287 lactations sampled between 2013 and 2015 for which all parameters had been recorded was available for the study. After filtering of the data set, 88,534 valid lactations were available for analysis. The cows were kept in 1,657 different farms and every cow was included only once in the study. Among these cows, 27,723 cows were dried off using antibiotics (AB group: 31.3\%) and 60,811 cows were dried off without antibiotics (non-AB group: $68.7 \%$ ).

\section{Milk Yield}

The average milk yield during the lactation (305 d) before drying off was significantly higher $(P<0.001)$ 
Table 1. Estimated effects of parameters recorded during the previous lactation (before dry-off) on milk yield (kg) in the subsequent lactation (mixed model analysis)

\begin{tabular}{|c|c|c|c|c|c|c|}
\hline \multirow[b]{2}{*}{ Parameter } & \multirow[b]{2}{*}{ Estimate } & \multirow[b]{2}{*}{$\mathrm{SE}$} & \multirow[b]{2}{*}{$t$-statistic } & \multirow[b]{2}{*}{ Significance } & \multicolumn{2}{|c|}{$95 \%$ CI } \\
\hline & & & & & Lower & Upper \\
\hline Dry off using antibiotics & 90.83 & 25.74 & 3,528 & 0.000 & 40.35 & 141.30 \\
\hline Clinical mastitis during previous lactation (305 d) & -31.70 & 38.37 & -0.826 & 0.409 & -106.91 & 43.51 \\
\hline Milk yield in previous lactation $(305 \mathrm{~d})$ & 0.68 & 0.02 & 40,058 & 0.000 & 0.65 & 0.71 \\
\hline Daily milk yield at dry-off & 61.83 & 2.31 & 26.656 & 0.000 & 57.28 & 66.38 \\
\hline SCC at dry-off & 0.02 & 0.02 & 1.188 & 0.235 & -0.02 & 0.06 \\
\hline
\end{tabular}

in the $\mathrm{AB}$ group $(7,920 \pm 1,816 \mathrm{~kg})$ compared with the non-AB group $(7,471 \pm 1,770 \mathrm{~kg})$. Additionally, daily milk yield at dry-off was significantly higher in cows of the AB group $(15.5 \pm 5.9 \mathrm{~kg} / \mathrm{d})$ than in cows of the nonAB group $(14.7 \pm 5.7 \mathrm{~kg} / \mathrm{d})$. The probability of drying off using antibiotics increased almost linearly with milk yield (Figure 1). The average milk yield in the subsequent lactation increased significantly in both groups (AB group: 8,129 $\pm 1,812 \mathrm{~kg}$; non-AB group: 7,825 \pm $1,245 \mathrm{~kg}$ ). Similar to the lactation before dry-off, milk yields were different between the groups; however, the increments from the previous to the subsequent lactation did not differ between the groups.

The following parameters were identified by the mixed model analysis to have significant effects on the outcome variable milk yield in the subsequent lactation: use of antibiotics at dry-off, milk yield in previous lactation, milk yield at dry-off, and SCC during 90 $\mathrm{d}$ before dry-off. The use of antibiotics had the most

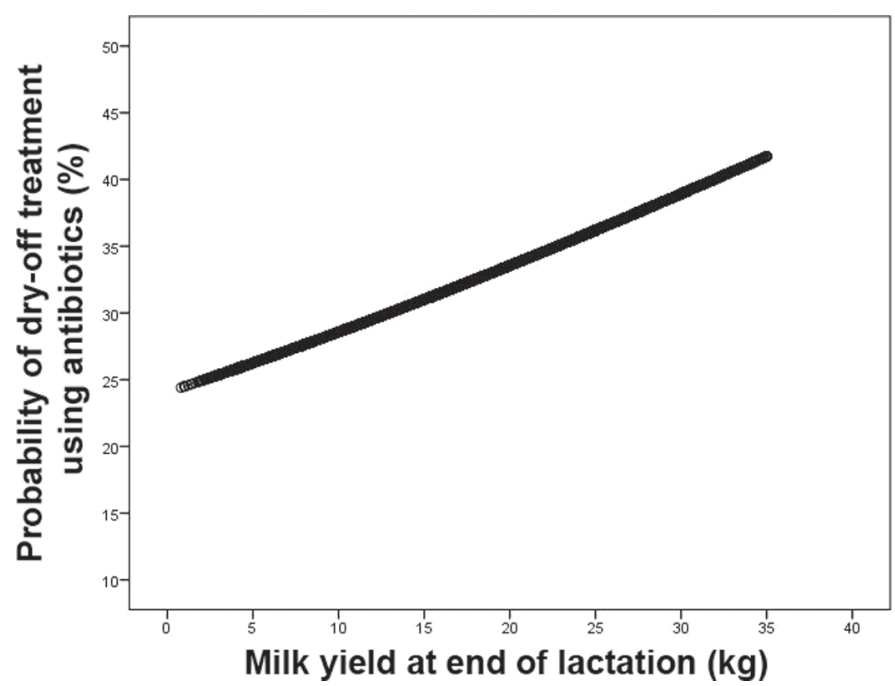

Figure 1. Probability of using antibiotics at dry-off associated with daily milk yield $(\mathrm{kg})$ at dry-off. dominant effect; it accounted for approximately 91 $\mathrm{kg}$ of milk production for the $\mathrm{AB}$ group in the subsequent lactation. No significant effects were found for frequency of clinical mastitis in previous lactation, $\mathrm{SCC}$ at dry off, the frequency of SCC >200,000 cells/mL in previous lactation, lactation number, year, season, farm, or veterinarian (Table 1 ).

\section{$S C C$}

The average SCC during the final $90 \mathrm{~d}$ of the lactation before drying off did not differ between the 2 groups (AB group: 76,238 $\pm 33,113$ cells $/ \mathrm{mL}$; non-AB group: $81,789 \pm 32,256$ cells $/ \mathrm{mL})$. The $\mathrm{SCC}$ at dry-off was not different in the AB group $(120,226 \pm 29,234$ cells/mL) compared with the non-AB group $(117,490$ $\pm 28,445$ cells $/ \mathrm{mL}$ ). Similar to milk yield, we detected a significant association $(P=0.008)$ between SCC at dry-off and the probability that antibiotics were used to dry off the cows (Figure 2): it was more likely that farmers and veterinarians used antibiotics at dry-off if the cow had an increased SCC at that time.

Except for lactation number, year, farm, veterinarian, and milk yield at dry-off, all other parameters recorded in the previous lactation influenced average SCC during first 90 DIM in the subsequent lactation. The use of antibiotics resulted in a lower $\mathrm{SCC}(1,500$ cells $/ \mathrm{mL}$ on average) in the subsequent lactation (Table 2).

\section{Mastitis Frequency During Previous and Subsequent Lactations}

The frequency of clinical mastitis was higher in the $\mathrm{AB}$ group $(9.3 \%)$ in the lactation before dry-off than in the non- $\mathrm{AB}$ group $(6.5 \%)$. This difference was still present in the subsequent lactation within 90 DIM, independently of the type of dry-off treatment $(\mathrm{AB}$ group: $7.9 \%$ mastitis, non-AB group: $4.7 \%$ ). The frequency of clinical mastitis within 90 DIM of the subsequent lactation was significantly higher in cows that 


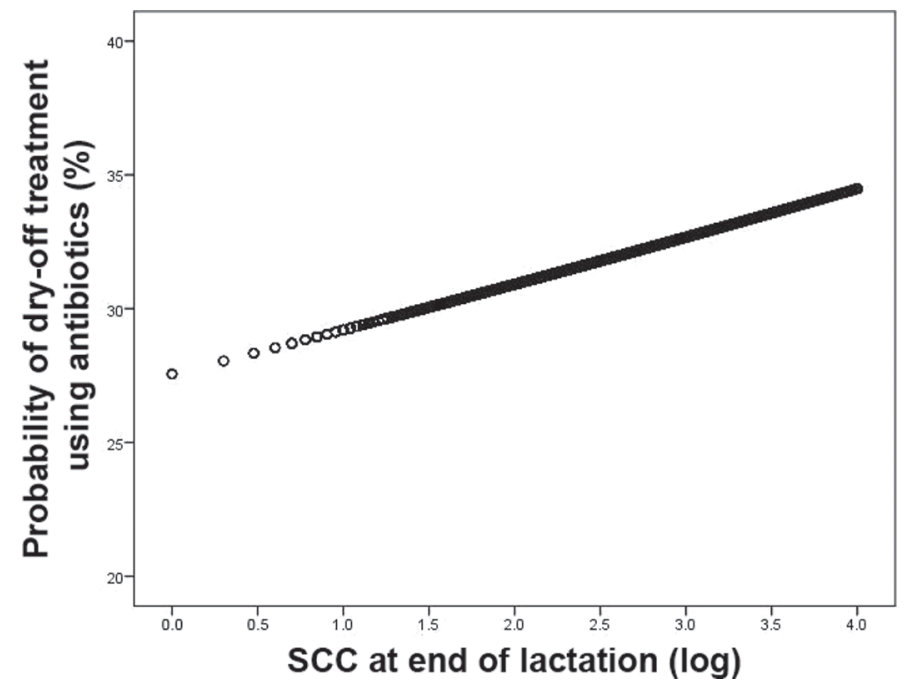

Figure 2. Probability of using antibiotics at dry-off associated with SCC at dry-off; SCC data are presented after log-transformation.

had a mastitis episode in the previous lactation than in cows that did not suffer from mastitis (Figure 3). We detected no significant effect of antibiotics used at dry-off on the frequency of clinical mastitis within 90 DIM of the subsequent lactation.

\section{Calculation of Cut-Off Values}

We aimed to calculate cut-off values for several parameters of previous lactation (milk yield of previous lactation, milk yield at dry-off, SCC during $90 \mathrm{~d}$ before dry-off, SCC at dry-off) that could be used to decide whether antibiotics should be used at dry-off. The ROC curve analysis failed to reach satisfactory sensitivity with a low false positive rate $(1-$ specificity) for any of the parameters. The areas under the curve ranged between 41.0 and $58.4 \%$, much lower than required for sensitivity yielding meaningful diagnosis. In other words, the cut-off values did not have any predictive power to justify a decision on specific dry-off treat-

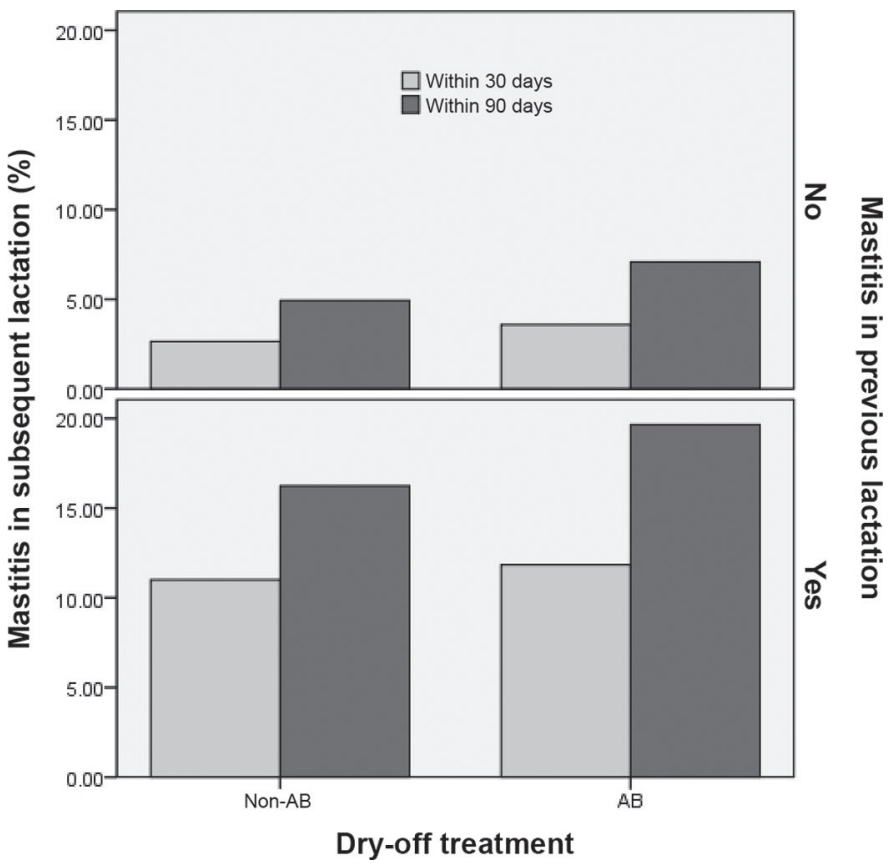

Figure 3. Frequency of mastitis during the lactation before dryoff treatments and in the subsequent lactation at 30 and 90 DIM in relation to dry-off treatment using or not using antibiotics [antibiotic $(\mathrm{AB})$ versus non- $\mathrm{AB}]$.

ment. The ROC curves for mastitis frequency within 90 DIM are shown in Figures 4 and 5 as examples for all other parameters.

\section{DISCUSSION}

In this study, the high percentage of cows that were dried off without antibiotics was unexpected. This finding indicates that farmers and veterinarians in Austria are applying the concept of selective dry-cow treatment and reducing the use of antibiotics at dry-off. This result is in contrast to a recent survey of dairy farmers in northern Germany, in which almost $80 \%$ claimed to be using blanket antibiotic dry-cow therapy (Bertulat et

Table 2. Estimated effects of parameters recorded during the previous lactation (before dry-off) on average SCC (log-transformed) until 90 d in milk during subsequent lactation (mixed model analysis)

\begin{tabular}{|c|c|c|c|c|c|c|}
\hline \multirow[b]{2}{*}{ Parameter } & \multirow[b]{2}{*}{ Estimate } & \multirow[b]{2}{*}{$\mathrm{SE}$} & \multirow[b]{2}{*}{$t$-statistic } & \multirow[b]{2}{*}{ Significance } & \multicolumn{2}{|c|}{$95 \% \mathrm{CI}$} \\
\hline & & & & & Lower & Upper \\
\hline Intercept & 1,549 & 0.052 & 30.200 & 0.000 & 1.448 & 1.650 \\
\hline Dry off using antibiotics & -0.155 & 0.014 & -10.893 & 0.000 & -0.182 & -0.127 \\
\hline Clinical mastitis during previous lactation & 0.065 & 0.021 & 3.160 & 0.002 & 0.024 & 0.106 \\
\hline Milk yield in previous lactation (305 d) & $2.07 \mathrm{E}-5$ & $9.16 \mathrm{E}-6$ & 2.260 & 0.024 & $2.74 \mathrm{E}-6$ & $3.86 \mathrm{E}-5$ \\
\hline Daily milk yield at dry-off & 0.001 & 0.001 & 1.118 & 0.264 & -0.001 & 0.004 \\
\hline Frequency of $\mathrm{SCC}>200,000$ cells $/ \mathrm{mL}$ in previous lactation & 0.061 & 0.003 & 18.310 & 0.000 & 0.054 & 0.067 \\
\hline SCC during final $90 \mathrm{~d}$ of previous lactation & $1.10 \mathrm{E}-4$ & $1.66 \mathrm{E}-5$ & 6.628 & 0.000 & $7.78 \mathrm{E}-5$ & $1.43 \mathrm{E}-4$ \\
\hline $\mathrm{SCC}$ at dry-off & $7.68 \mathrm{E}-5$ & $9.16 \mathrm{E}-6$ & 8.387 & 0.000 & $5.89 \mathrm{E}-5$ & $9.48 \mathrm{E}-5$ \\
\hline
\end{tabular}




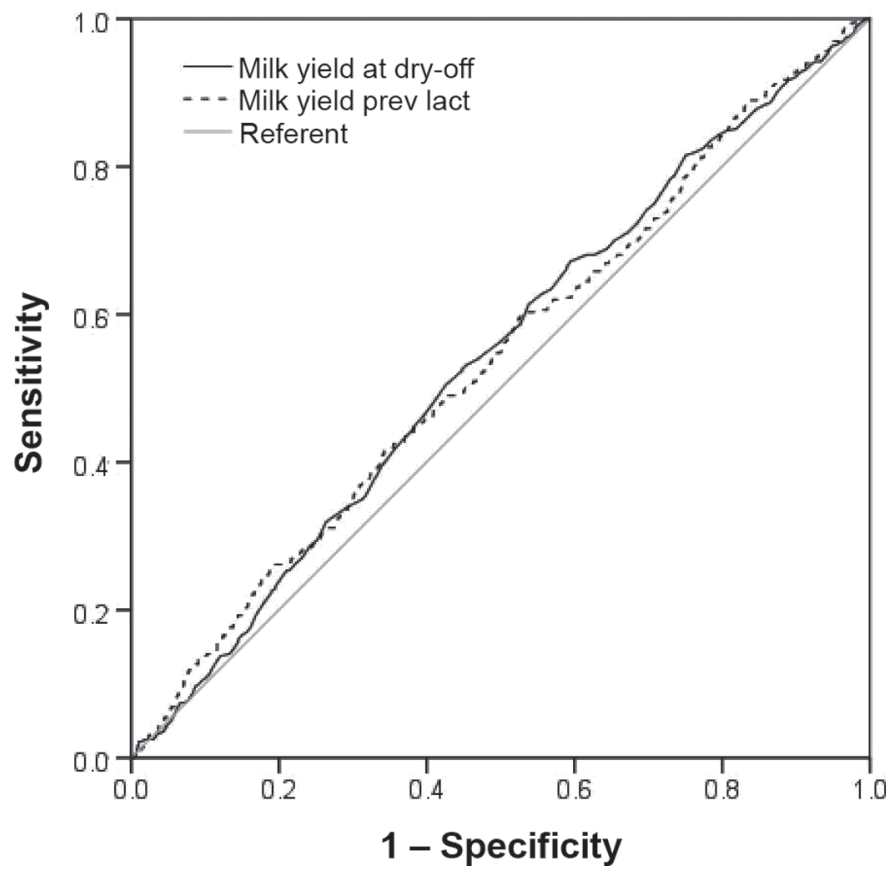

Figure 4. Receiver operating characteristic curves according to frequency of mastitis to d 90 in subsequent lactation through milk yield at dry-off (area under the curve $=54.0 \%$ ) and milk yield in previous lactation (area under the curve $=53.9 \%$ ) for antibiotic $(\mathrm{AB})$ dry-off treatment.

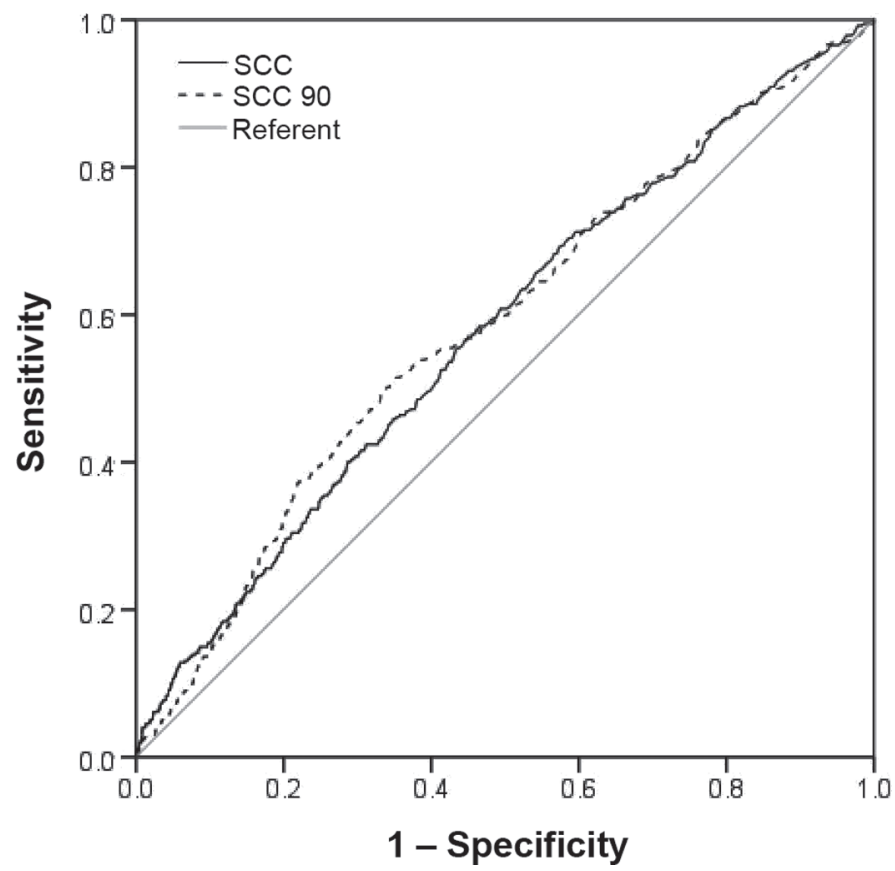

Figure 5. Receiver operating characteristic curves according to frequency of mastitis to d 90 in subsequent lactation through SCC at dry-off (area under the curve $=57.6 \%$ ) and SCC during the final 90 $\mathrm{d}$ of previous lactation (SCC 90; area under the curve $=58.4 \%$ ) for antibiotic $(\mathrm{AB})$ dry-off treatment al., 2015). Although farmers and advising veterinarians in Austria might be increasingly aware of their need to reduce the use of antimicrobial drugs, other possible explanations might be the different farm structure (small family farms in Austria and larger farms in Germany) and the high percentage of organic farms in Austria (21\%) compared with Germany (10\%).

The differences in daily milk yield in the previous lactation between $\mathrm{AB}$ and non- $\mathrm{AB}$ dry-off treatment reflect the fact that farmers and veterinarians tend to use antibiotic dry-off treatment more frequently in cows with higher milk yield than in cows with lower milk yield. One major result of the study was that antibiotic treatment at dry-off had a positive effect on milk yield in the subsequent lactation. Cows receiving $\mathrm{AB}$ dry-off treatment produced, on average, $91 \mathrm{~kg}$ more milk in the subsequent lactation (a substantial difference), and this association was adjusted for confounders such as DIM at dry-off, milk yield in previous lactation, cow, and herd. No comparable information is available in the literature but the most likely explanation is that antibiotics facilitated the cure of subclinical mastitis during the dry period.

Surprisingly, SCC of cows at the end of lactation did not differ significantly between the treatment groups, indicating that farmers and veterinarians did not appear to use SCC to decide whether antibiotics should be used at dry-off. This is in contrast to suggestions from the literature because SCC is thought to be useful in deciding on dry-off treatment (Rindsig et al., 1978; Torres et al., 2008; Rajala-Schultz et al., 2011; Bhutto et al., 2012; Scherpenzeel et al., 2014) and is reported to have moderate diagnostic value. Monthly SCC data are readily available to Austrian dairy farmers and veterinarians or could be estimated by the California Mastitis Test. We cannot explain why SCC was used less for decision-making in our study. Our second main hypothesis was that cows with increased SCC caused by subclinical mastitis during the previous lactation and dried off using antibiotic treatment would have lower SCC and lower frequency of clinical and subclinical mastitis in the subsequent lactation. As shown in the results, $\mathrm{AB}$ dry-off treatment resulted in a decrease in SCC of 1,500 cell $/ \mathrm{mL}$, on average, in the subsequent lactation. The analysis showed that SCC at dry-off and during the final $90 \mathrm{~d}$ had a significant but limited influence on the SCC in the first $90 \mathrm{~d}$ of the subsequent lactation. This is in contrast to studies such as Scherpenzeel et al. (2014), which suggested the application of cut-off values for SCC.

A major difference between the present study and other studies on dry-off treatment is the large data set, which means the study was conducted at the population rather than the sample level. This allows conclusions 
with high evidence for the population. However, the study has some limitations that need to be considered. Because bacterial culture results were not available for analysis, we cannot evaluate whether the spectrum of bacteria may have influenced the results. Robert et al. (2006) reported an increased relative risk (1.5 to 2.0) for IMI and mastitis in untreated cows, which was not corroborated by the present study. However, those authors also noted that antibiotic dry-off treatment is less protective against CNS and coliform infections, which might have contributed to the different results. Additionally, the application of internal teat sealants might be a potential confounder of the study because teat sealants may prevent IMI during the dry period either in combination with antibiotics or alone (Rabiee and Lean, 2013). We have no information about the use of teat sealants in the cows of the present study. However, internal teat sealants were not popular among Austrian farmers until very recently (fewer than 2,000 tubes/ yr sold in 2014; K. Markon, Zoetis Austria, Vienna, Austria; personal communication). Therefore, it seems reasonable to assume that the effect of teat sealants would be small in our data set. From 2016 on, the application of teat sealants has been recorded by using a specific code in the health monitoring system.

Although it has been shown that using antibiotics at dry-off generally results in substantially higher milk yield and a moderately decreased SCC in the subsequent lactation, the current study failed, despite the large data set, to identify cut-off values with sufficiently high diagnostic value for use in deciding whether to use antibiotics at dry-off. Including additional parameters such as results of bacterial culture or on-farm culture systems might increase the diagnostic value of cut-offs. Cut-off values might have to be determined for each herd individually, as suggested by Huijps and Hogeveen (2007) and Halasa et al. (2010). The results of our study do not contradict the assumption that blanket antibiotic treatment is no longer justifiable because resistance against antimicrobials is a growing problem. Although we were unable to develop cut-off values to aid in decision-making, our findings do not necessarily go against the potential benefits of selective dry-cow treatment.

\section{ACKNOWLEDGMENTS}

The authors thank D. Logue (University of Glasgow) for his help preparing the manuscript. We acknowledge the funding of the K-project ADDA-Advancement of Dairying in Austria. This project was supported by BMVIT (Austrian Ministry for Transport, Innovation and Technology, Vienna, Austria), BMWFW (Federal Ministry of Science, Research and Economy, Vienna,
Austria), the federal state of Lower Austria and the city of Vienna in the framework of COMET Competence Centers for Excellent Technologies. The COMET program is handled by the FFG (Austrian Research Promotion Agency, Vienna, Austria).

\section{REFERENCES}

Berry, E. A., and J. E. Hillerton. 2002. The effect of selective dry cow treatment on new intramammary infections. J. Dairy Sci. 85:112-121

Bertulat, S., C. Fischer-Tenhagen, and W. Heuwieser. 2015. A survey of drying-off practices on commercial dairy farms in northern Germany and a comparison to science-based recommendations. Vet. Rec. Open 2:e000068. https://doi.org/10.1136/vetreco-2014 -000068 .

Bhutto, A. L., R. D. Murray, and Z. Woldehiwet. 2012. California mastitis test scores as indicators of subclinical intramammary infections at the end of lactation in dairy cows. Res. Vet. Sci. 92:13-17.

Bradley, A. J., and M. J. Green. 2001. An investigation of the impact of intramammary antibiotic dry cow therapy on clinical coliform mastitis. J. Dairy Sci. 84:1632-1639.

Browning, J. W., G. A. Mein, M. Barton, T. J. Nicholls, and P. Brightling. 1990. Effects of antibiotic therapy at drying off on mastitis in the dry period an early lactation. Aust. Vet. J. 67:440-442.

Cameron, M., S. L. McKenna, K. A. MacDonald, I. R. Dohoo, J. P. Roy, and G. P. Keefe. 2014. Evaluation of selective dry cow treatment following on-farm culture: Risk of postcalving intramammary infection and clinical mastitis in the subsequent lactation. J. Dairy Sci. 97:270-284. https://doi.org/10.3168/jds.2013-7060.

Dingwall, R. T., D. F. Kelton, K. E. Leslie, and V. L. Edge. 2001. Deciding to dry off: Does level of production matter? Pages 69-79 in Proc. National Mastitis Council Meeting, Madison, WI. National Mastitis Council, Madison, WI.

Dingwell, R. T., K. E. Leslie, Y. H. Schukken, J. M. Sargeant, L. L. Timms, T. F. Duffield, G. P. Keefe, D. F. Kelton, K. D. Lissemore, and J. Conklin. 2004. Association of cow and quarter level factors at dry off and new intramammary infections in the dry period. Prev. Vet. Med. 63:75-89.

Dufour, S., A. Frechette, H. W. Barkema, A. Mussell, and D. Scholl. 2011. Invited review: Effect of udder health management practices on herd somatic cell count. J. Dairy Sci. 94:563-579.

Egger-Danner, C., B. Fürst-Waltl, W. Obritzhauser, C. Fürst, H. Schwarzenbacher, B. Grassauer, M. Mayerhofer, and A. Koeck. 2012. Recording of direct health traits in Austria-Experience report with emphasis on aspects of availability for breeding purposes. J. Dairy Sci. 95:2765-2777.

Egger-Danner, C., O. K. Hansen, K. Stock, J. E. Pryce, J. B. Cole, N. Gengler, and B. Heringstad. 2013. Challenges and benefits of health data recording in the context of food chain quality, management and breeding. ICAR Technical Series No 17. ICAR, Rome, Italy. http://www.icar.org/Documents/technical_series/tec_series _17_Aarhus.pdf.

Green, M. J., A. J. Bradley, G. F. Medley, and W. J. Browne. 2007. Cow, farm, and management factors during the dry period that determine the rate of clinical mastitis after calving. J. Dairy Sci. 90:3764-3776.

Green, M. J., L. E. Green, G. F. Medley, Y. H. Schukken, and A. J. Bradley. 2002. Influence of dry period bacterial intramammary infection on clinical mastitis in dairy cows. J. Dairy Sci. 85:25892599 .

Halasa, T., M. Nielen, T. van Werven, and H. Hogeveen. 2010. A simulation model to calculate costs and benefits of dry period interventions in dairy cattle. Livest. Sci. 129:80-87.

Halasa, T., M. Nielen, A. C. Whist, and O. Osteras. 2009b. Metaanalysis of dry cow management for dairy cattle. Part 2. Cure of existing intramammary infections. J. Dairy Sci. 92:3150-3157.

Halasa, T., O. Osteras, H. Hogeveen, T. van Werven, and M. Nielen. 2009a. Meta-analysis of dry cow management for dairy cattle. Part 
1. Protection against new intramammary infections. J. Dairy Sci. 92:3134-3149.

Hassan, Z., R. C. Daniel, D. O'Boyle, and A. J. Frost. 1999. Effects of dry cow intramammary therapy on quarter infections in the dry period. Vet. Rec. 145:635-639.

Huijps, K., and H. Hogeveen. 2007. Stochastic modeling to determine the economic effects of blanket, selective, and no dry cow therapy. J. Dairy Sci. 90:1225-1234.

Huxley, J. N., M. J. Green, L. E. Green, and A. J. Bradley. 2002. Evaluation of the efficacy of an internal teat sealer during dry period. J. Dairy Sci. 85:551-561.

Pearson, J. K. L. 1950. The use of penicillin in the prevention of $C$. pyogenes infections of the non-lactating udder. Vet. Rec. 62:166169.

Pearson, J. K. L. 1951. Further experiments in the use of penicillin in the prevention of $C$. pyogenes infections of the non-lactating bovine udder. Vet. Rec. 63:215-220.

Rabiee, A. R., and I. J. Lean. 2013. The effect of internal teat sealant products (Teatseal and Orbeseal) on intramammary infection, clinical mastitis, and somatic cell counts in lactating dairy cows: A meta-analysis. J. Dairy Sci. 96:6915-6931.

Rajala-Schultz, P. J., A. H. Torres, and F. J. Degraves. 2011. Milk yield and somatic cell count during following lactation after selective treatment of cows at dry off. J. Dairy Res. 78:489-499.

Rindsig, R. B., R. G. Rodewald, A. R. Smith, and S. L. Spahr. 1978. Complete versus selective dry cow therapy for mastitis control. J. Dairy Sci. 61:1483-1497.

Robert, A., P. Roussell, N. Bareille, D. Ribaud, F. Serieys, V. Heuchel, and H. Seegers. 2008. Risk factors for new intramammary infec- tions during the dry period in cows submitted to selective antibiotic therapy. Animal 2:247-254.

Robert, A., H. Seegers, and N. Bareille. 2006. Incidence of intramammary infections during the dry period without or with antibiotic treatment in dairy cows - A quantitative analysis of published data. Vet. Res. 37:25-48.

Robinson, T. C., E. R. Jackson, and A. Marr. 1988. Mastitis incidence in quarters with different infection status at drying off and calving in two treatment groups. Br. Vet. J. 144:166-173.

Roy, J.-P., D. Du Tremblay, L. DesCoteaux, S. Messier, D. Scholl, and E. Bouchard. 2009. Evaluation of the California Mastitis Test as a pre-calving treatment selection tool for Holstein heifers. Vet. Microbiol. 134:136-142.

Scherpenzeel, C. G. M., I. E. M. den Uijl, G. van Schaik, R. G. M. Olde-Riekerink, J. M. Keurentjes, and T. J. G. M. Lam. 2014 Evaluation of the use of dry cow antibiotics in low somatic cell counts cows. J. Dairy Sci. 97:3606-3614.

Smith, A., F. K. Neave, F. H. Dodd, and G. C. Brander. 1966. Methods of reducing the incidence of udder infection in dry cows. Vet. Rec. 79:233-236.

Smith, A., D. R. Westgarth, M. R. Jones, F. K. Neave, F. H. Dodd, and G. C. Brander. 1967. Methods of reducing the incidence of udder infection in dry cows. Vet. Rec. 81:504-510.

Torres, A. H., P. J. Rajala-Schultz, F. J. Degraves, and K. H. Hoblet. 2008. Using dairy herd improvement records and clinical mastitis history to identify subclinical mastitis infections at dry-off. J. Dairy Res. 75:240-247. 